J. Clin. Chem. Clin. Biochem.

Vol. 28, 1990, pp. 943-947

(C) 1990 Walter de Gruyter \& Co. Berlin $\cdot$ New York

\title{
Enzyme Immunoassay of Testosterone Using Nitrocellulose Discs as the Solid Phase
}

\author{
By $A$. K. Samanta and E. Ali \\ Indian Institute of Chemical Biology, Calcutta, India
}

(Received January 31/April 17/June 29, 1990)

\begin{abstract}
Summary: An enzyme immunoassay (EIA) for the measurement of serum testosterone has been developed using nitrocellulose paper discs as the solid support. The paper discs (6 $\mathrm{mm}$ diameter) coated with testosteronespecific antibody were incubated with testosterone and testosterone-peroxidase conjugate in glass tubes. The amount of testosterone present in samples could be estimated from the bound peroxidase activity. The assay was validated by comparison with a microtitre plate-based ELISA and a commercial radioimmunoassay (RIA) kit. The correlation coefficient between RIA and EIA was 0.84 . No significant cross reactivity was observed with other steroids, except for dihydrotestosterone. The inter- and intra-assay coefficients of variation were 4.4 and $9.6 \%$ respectively. The preservation and transport of the coated paper discs are convient and the overall cost of the method is less than that of other methods.
\end{abstract}

\section{Introduction}

Measurement of serum testosterone provides useful information of diagnostic significance in many physiological abnormalities, including hypogonadism, testicular feminization in man and virilizing disorders, hirsutism, Stein-Leventhal syndrome as well as ovarian and adrenal tumours in women. The first EIA for testosterone was reported by Rajkowski et al. who immobilized anti-testosterone antibody by copolymerization with human serum albumin or by conjugation to thyroglobulin immobilized on cellulose (1, 2). However, polystyrene tubes, beads and microtitre plates have now become standard solid phases for immobilization of antibodies and antigens in EIA $(3-5)$, and some of these have also been used for testosterone assay $(6-8)$. Although nitrocellulose paper has been extensively used for protein blotting, its use for immobilization of protein antigens and antibodies for EIA has been limited. A large number of nitrocellulose paper discs can be coated under uniform conditions by immersion in a protein solution, and preservation and transport of such coated discs are more convenient than microtitre plates and tubes. In this respect the use of nitrocellulose paper discs offers a definite advantage over many other solid phases.

In this report, we describe an enzyme immunoassay technique for serum testosterone using nitrocellulose discs as solid phase and horse radish peroxidase as the enzyme label. The sensitivity and the precision of the method are comparable with those using microtitre plates, and the method is suitable for the measurement of the hormone at physiological levels.

\section{Materials and Methods}

Bovine serum albumin (Cohn fraction $\mathrm{V}$ ), horse radish peroxidase (Sigma Type VI, RZ 3.0), testosterone, $5 \alpha$-dihydrotestosterone, androstenedione, dehydroepiandrosterone, 17 $\beta$-oestradiol, oestriol, (aminooxy)acetic acid (carboxymethoxylamine hemihydrochloride), N-hydroxysuccinimide, dicyclohexylcarbodiimide, $o$-phenylenediamine and polyoxyethylene sorbitan monolaurate (Tween 20) were purchased from Sigma Chemical Co., USA. Nitrocellulose paper (Trans Blot) was from Bio-Rad Laboratories, California USA; flat bottomed microtitre plates were from Costar, Cambridge, Massachusetts, USA. The ra- 
dioimmunoassay kit was obtained from Radioassay System Laboratories Inc., Carson, California, USA, and Sephadex G25 and Sepharose 4B from Pharmacia Fine Chemicals, Uppsala, Sweden. All other chemicals and reagents used were of analytical grade.

Preparation of testosterone-3-(O-carboxymethyl)oxime

Testosterone-3-(O-carboxymethyl)oxime (9) was prepared according to the method of Janoski et al. (10). To $144 \mathrm{mg}$ testosterone $(0.5 \mathrm{mmol})$ dissolved in $2.5 \mathrm{ml}$ methanol, pyrrolidine $(80 \mu \mathrm{l})$ was added dropwise with constant stirring. A yellowish precipitate was formed and another $80 \mu \mathrm{l}$ of the pyrrolidine was added to the mixture followed by $128 \mathrm{mg}(1.17 \mathrm{mmol})$ of (aminooxy)acetic acid. The reaction mixture was placed in a water bath at $50{ }^{\circ} \mathrm{C}$ for 5 minutes. The precipitate dissolved and a clear solution was obtained. The methanol was removed by distillation and the residue extracted by treatment with $1 \mathrm{ml}$ of $0.5 \mathrm{~mol} / 1 \mathrm{HCl}$ and $5 \mathrm{ml}$ of ethyl acetate. The ethyl acetate layer was washed with water, dried over sodium sulphate and evaporated. The residue was crystallized from benzene-petroleum ether mixture as colourless needles; yield $83 \%$, mp. $174-$ $176{ }^{\circ} \mathrm{C}$ (in 1. c. (9): m. p. $179-181{ }^{\circ} \mathrm{C}$ ). The compound was fully characterized from its NMR spectrum.

\section{Preparation of immunogen}

Testosterone-3-(O-carboxymethyl)oxime was conjugated to bovine serum albumin by the method of Mattox et al. (11). A solution of $3 \mathrm{mg}$ of the oxime in $1 \mathrm{ml}$ of dimethylformamide was treated with $5 \mathrm{mg}$ of dicyclohexylcarbodiimide and $2 \mathrm{mg}$ of N-hydroxysuccinimide overnight at $4{ }^{\circ} \mathrm{C}$. The activated ester solution was allowed to react with $10 \mathrm{mg}$ of bovine serum albumin in $1 \mathrm{ml}$ sodium bicarbonate $(0.13 \mathrm{~mol} / \mathrm{l})$ solution for $2 \mathrm{~h}$. The reaction mixture was then dialysed against phosphate buffer, $25 \mathrm{mmol} / \mathrm{l}, \mathrm{pH} 7.5$, and purified by column chromatography on Sephadex G-25 $(1.5 \times 40 \mathrm{~cm})$ using the same buffer as the mobile phase. Protein fractions were pooled, lyophilised and stored at $-20^{\circ} \mathrm{C}$.

\section{Immunisation procedure}

Antibody was raised in New Zealand white rabbits following the same protocol as described earlier for oestradiol (12). Satisfactory antibody titres were obtained after 5 months. Blood was collected by cardiac puncture and the antibody was precipitated from the serum with ammonium sulphate $(50 \%$ saturation). The precipitation step was repeated three times and the final precipitate was dissolved in $25 \mathrm{mmol} / \mathrm{l}$ sodium phosphate buffer ( $\mathrm{pH}$ 6.8), dialysed against the same buffer containing sodium chloride $(9 \mathrm{~g} / \mathrm{l})$ at $4{ }^{\circ} \mathrm{C}$ and then passed through a bovine serum albumin-Sepharose $4 \mathrm{~B}$ immunoadsorbent column $(1.3 \times 4 \mathrm{~cm}$ for $20 \mathrm{ml}$ serum $)$ to remove anti-bovine serum albumin antibodies. The IgG solution was then stirred with activated charcoal $(20 \mathrm{~g} / \mathrm{l})$ for 2 hours at room temperature to remove endogenous bound steroids, and the supernatant was stored at $-20^{\circ} \mathrm{C}$ in $1 \mathrm{ml}$ aliquots.

\section{Preparation of the enzyme conjugate}

Horse radish peroxidase $(5 \mathrm{mg})$ was conjugated with testosterone-3-(O-carboxymethyl)oxime $(2 \mathrm{mg})$ by the activated ester method as described for bovine serum albumin. The enzyme conjugate was dialysed against phosphate buffer, $25 \mathrm{mmol} / \mathrm{l}$, $\mathrm{pH} 7.5$ and submitted to column chromatography on Sephadex G-25 $(1.5 \times 40 \mathrm{~cm})$ using the same buffer. Working solutions of the enzyme conjugate were prepared by dilution with phosphate buffer, $50 \mathrm{mmol} / \mathrm{l}, \mathrm{pH} 7.5$ containing bovine serum albumin $(1 \mathrm{~g} / \mathrm{l})$ and thiomersal $(0.1 \mathrm{~g} / \mathrm{l})$.
The substrate for horse radish peroxidase assay was citratephosphate buffer $(0.1 \mathrm{~mol} / \mathrm{l}) \mathrm{pH} 6.0$, containing $o$-phenylenediamine hydrochloride $(3.87 \mathrm{mmol} / \mathrm{l})$ and $\mathrm{H}_{2} \mathrm{O}_{2}(0.2 \mathrm{mmol} / \mathrm{l})$. The enzyme reaction was stopped by addition of $50 \mu \mathrm{l}$ of $2 \mathrm{~mol} / \mathrm{l}$ $\mathrm{H}_{2} \mathrm{SO}_{4}$, and the colour measured at $492 \mathrm{~nm}$, either with a microplate reader (Bio-Rad) or a spectrophotometer.

\section{Determination of steroid : protein ratio}

The molar ratio of steroid to protein in the enzyme conjugate was determined from the ratio of absorbances at 255 and 403 $\mathrm{nm}$ of the conjugate, using a standard curve (fig. 1) prepared by plotting the $A_{255} / A_{403}$ ratios against the steroid/protein ratios of solutions containing known amounts of the steroid derivative and the enzyme in different proportions. For the albumin conjugate the ratio $A_{255} / A_{280}$ was used.

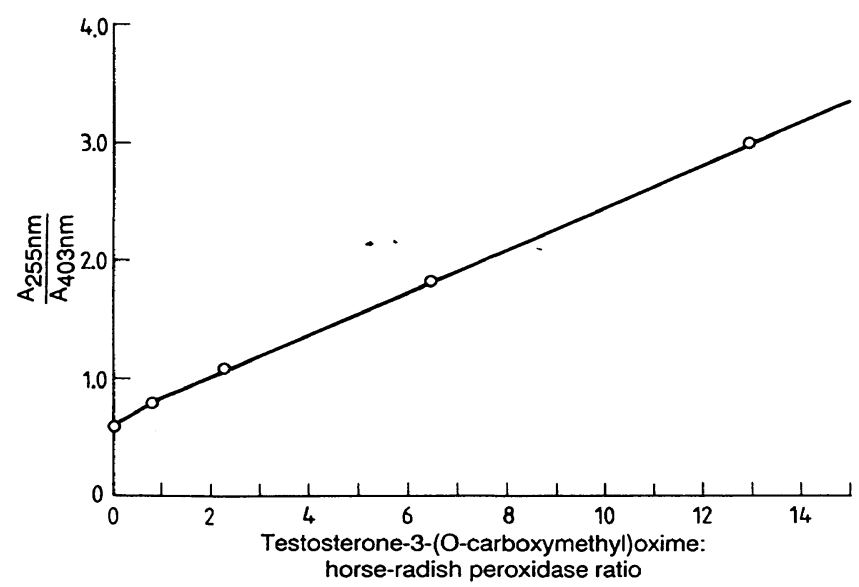

Fig. 1. Standard curve for determination of degree of conjugation in testosterone-horse radish peroxidase conjugate.

\section{Preparation of coated plates}

Microtitre plates were incubated with antibody $(200 \mu \mathrm{l} /$ well $)$ diluted in phosphate buffer, $50 \mathrm{mmol} / \mathrm{l}, \mathrm{pH} 7.5$, at room temperature for $2 \mathrm{~h}$ and then at $4{ }^{\circ} \mathrm{C}$ overnight. The plate was washed three times with wash buffer and the bovine serum albumin solution $(200 \mu \mathrm{l} / \mathrm{well})$ was added and incubated at room temperature for $1 \mathrm{~h}$. The plate was then dried by inversion on a blotting paper. The sealed plates could be preserved at $4{ }^{\circ} \mathrm{C}$ up to six months without significant loss of immunoreactivity.

\section{Preparation of coated nitrocellulose discs}

Round discs (6 mm diameter) of nitrocellulose paper were cut by a hand paper puncher. The discs were gently shaken for $3 \mathrm{~h}$ at room temperature in a petri dish containing suitably diluted testosterone antibody. Then the papers were washed twice with wash buffer and incubated with the blocking solution for $1 \mathrm{~h}$ at room temperature with gentle shaking. After washing the paper discs three times with the wash buffer, they were stored moist at $4{ }^{\circ} \mathrm{C}$ in a sealed glass container.

\section{Extraction of testosterone from serum}

To $100 \mu \mathrm{l}$ of serum in a $12 \mathrm{~mm} \times 75 \mathrm{~mm}$ glass test tube was added an equal amount of distilled methanol followed by $1 \mathrm{ml}$ of distilled ethyl acetate, and the mixture was vortexed and centrifuged at $300 \mathrm{~min}^{-1}$ for 5 minutes. The clear supernatant was decanted into a $10 \mathrm{ml}$ conical flask. To the residue, $0.5 \mathrm{ml}$ of ethyl acetate was added and centrifuged again and the 
supernatant was collected in the same flask. The combined ethyl acetate extract was evaporated on a steam bath. The dried material was dissolved in $400 \mu \mathrm{l}$ of bovine serum albumin solution and this solution was used for assay.

\section{Wash buffer}

Sodium potassium phosphate buffer, $58 \mathrm{~mol} / \mathrm{l}, \mathrm{pH} 7.2$, containing Tween-20 $(0.5 \mathrm{ml} / \mathrm{l})$.

\section{Bovine serum albumin solution}

Phosphate-buffered saline containing $1 \mathrm{~g} / \mathrm{l}$ bovine serum albumin and $0.1 \mathrm{~g} / 1$ thiomersal. This solution was used for blocking nitrocellulose papers and microtitre plates, and also for the preparation of testosterone standards and samples.

\section{Testosterone standards}

A stock solution of testosterone $(1 \mathrm{~g} / \mathrm{l})$ was prepared in $90 \%$ ethanol. Working standards were prepared by dilution with the bovine serum albumin solution.

\section{Radioimmunoassay}

Radioimmunoassay of testosterone in serum sample was carried out by the direct method without extraction, using a ${ }^{125}$ I-labelled testosterone kit according to the manufacturer's protocol. Briefly, to $50 \mu \mathrm{l}$ of the serum or standard were sequentially added, $0.1 \mathrm{ml}$ of steroid binding globulin inhibitor solution, 0.5 $\mathrm{ml}$ of $\left.{ }^{125} \mathrm{I}\right]$ testosterone and $0.5 \mathrm{ml}$ of antitestosterone antibody solutions. The samples were vortexed and incubated at $37^{\circ} \mathrm{C}$ for 120 minutes. After addition of $0.1 \mathrm{ml}$ of second antibody, the mixture was incubated at $37{ }^{\circ} \mathrm{C}$ for a further 60 minutes. After centrifugation the bound radioactivity of the precipitates was counted.

\section{Protocol for testosterone assay}

1. To antibody-coated plate or discs add $100 \mu \mathrm{l}$ of standard/ sample and incubate for $2 \mathrm{~h}$ at $37^{\circ} \mathrm{C}$.

2. Add $50 \mu$ l of enzyme conjugate and incubate for $1 \mathrm{~h}$ at room temperature and wash three times.

3. Add substrate $(200 \mu \mathrm{l} /$ well or $1 \mathrm{ml} /$ tube $)$ and incubate for 45 min at room temperature.

4. Add $2 \mathrm{~mol} / 1 \mathrm{H}_{2} \mathrm{SO}_{4},(50 \mu \mathrm{l} /$ well or $500 \mu \mathrm{l} /$ tube $)$ and read absorbance at $492 \mathrm{~nm}$.

\section{Results and Discussion}

Because of the low level of the hormone in females, any testosterone assay must be highly sensitive. As the hormone levels are different in male and female, the assay should also cover a wide range of hormone concentrations. The present investigation was undertaken to ascertain the suitability of nitro-cellulose paper as a solid phase for such a demanding assay.

Testosterone-3-(O-carboxymethyl)oxime was coupled to bovine serum albumin and horse radish peroxidase by the activated ester method and the steroid : protein ratios in the conjugates were found to be $22: 1$ and $5.5: 1$ respectively.
No significant difference was observed when phosphate buffer $(50 \mathrm{mmol} / \mathrm{l}, \mathrm{pH} 7.5)$ and carbonate buffer $(50 \mathrm{mmol} / \mathrm{l}, \mathrm{pH}$ 9.6) were used for coating either the microtitre plates or the nitrocellulose discs; phosphate buffer was used in the present work.

\section{Sample preparation}

Direct assay of testosterone in serum diluted with phosphate-buffered saline containing $1 \mathrm{~g} / 1$ bovine serum albumin gave analytical values for the steroid that were erroneously low. This was not unexpected as testosterone is known to bind strongly to several plasma proteins $(13,14)$; addition of 8-anilino-1naphthalene sulphonic acid $(0.4 \mathrm{~g} / \mathrm{l})$ did not release the steroid from the binding proteins. The extraction procedure, however gave satisfactory results. The recovery of the steroids as determined by assay of the extracted steroid added to charcoal-stripped serum, and comparison with values obtained by dissolving the same amount of steroid in the assay buffer showed that the recovery was almost complete $(87-94 \%)$.

\section{Sensitivity}

The standard curves obtained for both the solid phases, using the optimized antibody dilution of $1: 4000$ and the enzyme conjugate dilution $1: 1000$ are shown in figure 2 . The two standard curves are almost identical. The lowest amount measurable is $5 \mathrm{pg}$ per tube or well, corresponding to $0.2 \mu \mathrm{g} / \mathrm{l}$ of serum.

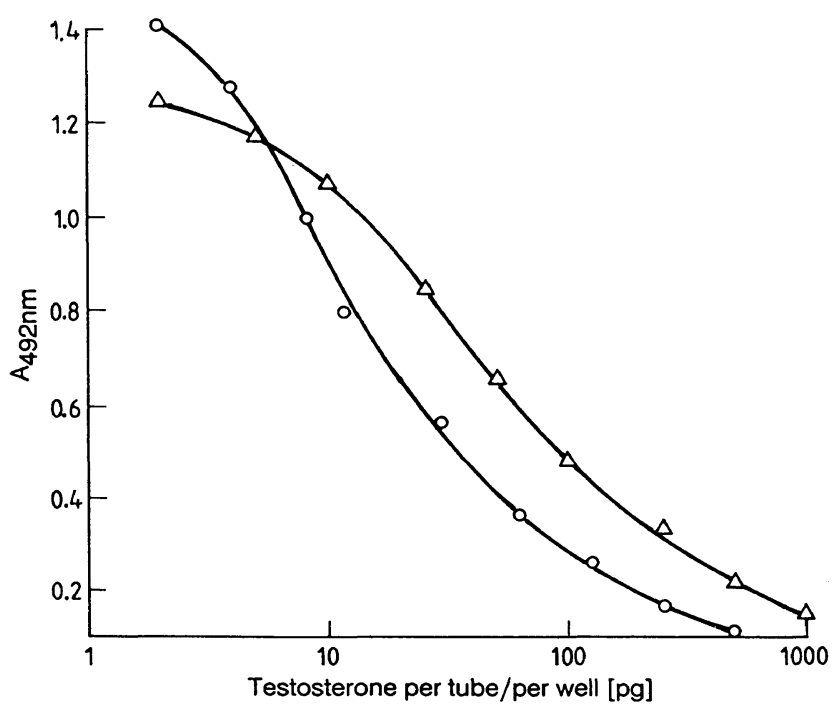

Fig. 2. Standard curves for measurement of testosterone using nitrocellulose paper discs $(0-0)$ and microtitre plate $(\triangle-\triangle)$. 
Precision, reproducibility and validation of the assay

The inter- and intra-assay coefficients of variation were $4.4 \%$ (mean \pm S. D.: $116.4 \pm 5.2 \mathrm{pg} /$ tube; $\mathrm{n}=10$ ) and $9.6 \%$ (mean \pm S. D.: $118.0 \pm 11.4 \mathrm{pg} /$ tube; $\mathrm{n}=7$ ). The testosterone levels of 52 serum samples measured by the present method and by a commercial RIA kit showed good correlation (correlation coefficient 0.84 ), the regression equation being $\mathrm{y}=0.96 \mathrm{x}+0.24$ where $\mathrm{x}=$ RIA value and $\mathrm{y}=$ EIA value (fig. 3).

Although the overall correlation of the EIA and RIA values is satisfactory, considerable discrepancies between the two methods were observed for a few samples, possibly due to handling errors during the sample preparation step for EIA.

\section{Cross-reactivity}

The cross reactivity of the antibody towards other closely related steroids at $50 \%$ displacement level as determined by the microtitre plate method is shown in table 1. Only dihydrotestosterone showed significant cross reactivity. High cross reactivity of dihydrotestosterone towards testosterone antibody has also been reported by earlier workers $(7,8)$.

Nitrocellulose paper discs have been used for the simultaneous detection in serum of IgE antibodies against several allergens using the dot method (15). It has been shown to be an excellent solid phase for radioimmunoassays, being able to bind five times more protein than standard microplate wells (16). It can be seen from data presented here that nitrocellulose paper is also a suitable solid phase for quantitative enzyme immunoassay. The coated discs

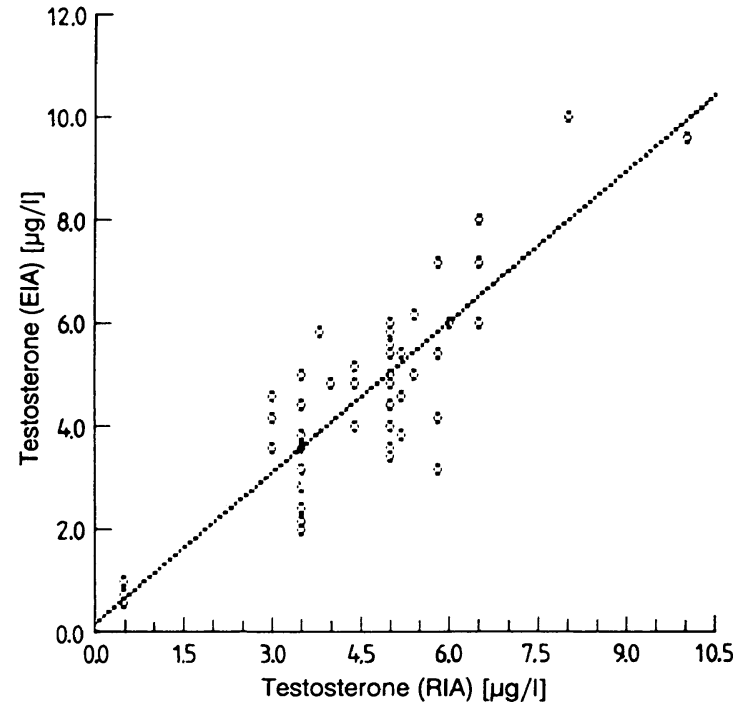

Fig. 3. Correlation of testosterone values found by RIA and by nitro-cellulose paper-based EIA in serum samples.

Tab. 1. The cross reactivity of the testosterone antibody with related steroids

\begin{tabular}{lc}
\hline Steroids & $\%$ Cross reactivity \\
\hline 1. Testosterone & 100.00 \\
2. 5 $\alpha$-Dihydrotestosterone & 28.00 \\
3. Androstenedione & 0.03 \\
4. Dehydroepiandrosterone & 0.02 \\
5. 17 $\beta$-Oestradiol & 0.05 \\
6. Oestriol & 0.01 \\
7. Progesterone & 0.01 \\
\hline
\end{tabular}

showed no significant loss of immunoreactivity after storage at $4{ }^{\circ} \mathrm{C}$ for up to 6 months. Since coating, washing and preservation of such discs are easy, and an ELISA reader is not required, the method should find wider applicability.

\section{References}

1. Rajkowski, K. M., Cittanova, N., Urios, P. \& Joyle, M. P. (1977) An enzyme-linked immunoassay of testosterone. Steroids $30,129-137$.

2. Rajkowski, K. M., Cittanova, N., Desfosses, B. \& Joyle, M. P. (1977) The conjugation of testosterone with horse radish peroxidase and a sensitive enzyme immunoassay for the conjugate. Steroids 29, $701-713$.

3. Tijssen, P. (1985) The immobilization of immunoreactants on solid phases. In: Laboratory Techniques in Biochemistry and Molecular Biology 15 (Burdon, R. H. \& Van Knippenberg, P. H., eds.) Elsevier: New York, pp. 297-328.

4. Engvall, E., Jonsson, K. \& Perlmann, P. (1971) Enzyme linked immunoabsorbent assay, II. Quantitative assay of protein antigen, immunoglobulin $\mathrm{G}$, by means of enzymelabelled antigen and antibody coated-tubes. Biochim. Biophys. Acta 251, 427-434
5. Tanaka, M. \& Kato, K. (1982) A sensitive enzyme immunoassay system for the measurement of $\beta$-thromboglobulin in plasma and urine. Clin. Chim. Acta 123, 111-119.

6. Bosch, A. M. G., Steven, W. H. J. M., Van Wijngaarden, C. J. \& Schuurs, A. H. W. M. (1978) Solid phase enzyme immunoassay (EIA) of testosterone. Z. Analyt. Chem. 290, 98.

7. Elder, P. A. \& Lewis, J. G. (1985) An enzyme linked immunosorbent assay (ELISA) for plasma testosterone. J. Steroid Biochem. 22, 635-638.

8. Marcus, G. J. \& Durnford, R. (1986) A simple enzyme linked immunosorbent assay for testosterone. Steroid 46, 975-986.

9. Erlanger, B. F., Borek, F., Beiser, S. M. \& Lieberman, S. (1957) Preparation and characterization of conjugates of bovine serum albumin with testosterone and with cortisone. J. Biol. Chem. 228, 713-727. 
10. Janoski, A. H., Shulman, F. C. \& Wright, G. E. (1974) Selective 3-(O-carboxymethyl)oxime formation in steroidal 3,20-diones for hapten immunospecificity. Steroids 23, 49-64.

11. Mattox, V. R., Litwiller, R. D. \& Nelson, A. N. (1979) A comparison of procedures for attaching steroidal glucosiduronic acids to bovine serum albumin. J. Steroid Biochem. $10,167-172$.

12. Dhar, T. K., Samanta, A. K. \& Ali, E. (1988) Homogeneous enzyme immunosassay of estradiol using estradiol-3-O-carboxymethyl ether as hapten. Steroids $51,519-526$.

13. Dunn, J. F., Nisula, B. C. \& Rodbard, D. (1981) Transport of steroid hormones: Binding of 21 endogenous steroids to both testosterone binding globulin and corticosteroid binding globulin in human plasma. J. Clin. Endocrinol. Metab. $53,58-68$.
14. Anderon, D. C. (1974) Sex hormone binding globulin. Clin. Endocrinol. 3, 69-96.

15. Walsch, B. J., Wrigley, C. W. \& Baldo, B. A. (1984) Simultaneous detection of IgE binding to several allergens using nitrocellulose poly discs. J. Immunol. Methods 66, $99-102$.

16. Davis, J. W., Angel, J. M. \& Bowen, J. M. (1984) A quantitative immunobinding radioimmunoassay for antigen attached to nitrocellulose paper. J. Immunol. Methods $67,271-278$

\section{Dr. Esahak Ali}

Indian Institute of Chemical Biology

4, Raja S. C. Mullick Road

Calcutta -700032 . India 
